\title{
THE CHONDROCRANIUM OF A 20 MM. HUMAN EMBYRO
}

JOHN D. KERNAN, JR.

From the Anatomical Laboratory of Columbia University

NINE PLATES

The human chondrocrania of early stages previously described have been those of 17, 18.5 and $23 \mathrm{~mm}$. embryos by Van Noorden ('87), of a $30 \mathrm{~mm}$. embyro by Jacoby ('94), of 13, 14, 17, and $28 \mathrm{~mm}$. embryos by Levi ('00), and of a $40 \mathrm{~mm}$. embyro by Macklin ('14). As in embyros of these early periods changes by growth are exceedingly rapid, it will be seen there are intervals to be filled.

The chondrocranium here described is that of a $20 \mathrm{~mm}$. human embyro, Columbia collection, no. 325 , reconstructed after the method of Born, at a magnification of 75 diameters.

According to Gaupp ('00), the chondrocranium comprises four primary regions, named from behind forward, the regio occipitalis, regio otica, regio orbito-temporalis, and the regio ethmoidalis (fig. 1). The structures comprising these are grouped about a central bar of cartilage to which each is joined. This scaffold is divided into two parts, chordal and praechodral (Kolliker, '49), because of the fact that the notochord extends into the first and not into the second. The pars chordalis includes the occipital and otic regions; the pars praechordalis, the orbitotemporal and ethmoid. The two divisions are not in the same horizontal plane but form (fig. 2) an angle in the orbito-temporal region of $65^{\circ}$, the apex of the angle being at the corpus sphenoidale. The proximal section is called the planum basale, the distal forms the interorbital septum and the mesethmoid (fig. 1).

The planum basale forms the main part of the floor of the skull. It extends from the foramen magnum caudally ${ }^{1}$ to the

1 Terms of direction are used here and throughout this article with reference to the basicranial axis. 
crista transversa cranially, which marks its junction with the sphenoid body. At its caudal end it divides into two branches which join on either side the partes laterales of the occipital region. Craniad to the occipital region it has on either side the large oval masses of cartilage which make up the otic capsules. These, with the plates of cartilage which extend them dorsally form the side walls of the skull in the otic region.

Craniad to the otic region, the basal plate joins the sphenoid body. Side walls are here lacking. In their place we see two processes on each side, caudal and ventral, the alae temporales; cranial and dorsal, the alae orbitales. From the crista transversa a prominent dorsum sellae springs upward.

With the vertebral column in the vertical position, the planum as it extends ventrad, rises in level. The slope is not uniform. Caudally in the occipital region, and cranially approaching the sphenoid, there is a fairly sharp rise. Between these sloping areas is a region which is horizontal. Thus the basal plate in its sagittal extension shows two angles. The first, at the junction of the caudal inclined area and the horizontal portion, points dorsad. The second, at the junction of the ventral inclined area and horizontal portion, points ventrad. In his series of models of human chondrocrania Levi demonstrated that a change of level of the basal plate (the vertebral column being held vertical) has a great influence on the course of development of the skull. His youngest embyro $(13 \mathrm{~mm}$.) showed the basal plate, in so far as it was developed, horizontal and straight. A $17 \mathrm{~mm}$. embyro showed a condition much like that described above for the $20 \mathrm{~mm}$. a horizontal middle region joined at either end by inclined areas which form angles with it. His oldest embyro (28 mm.) showed a basal plate with almost. vertical areas caudally and cranially, having a portion less steep between them. Thus the basal plate in this embryo showed the same angles as that of the earlier embryo and in addition the plate as a whole had here changed its level.

Consideration of the conditions found in all these embryos would appear to show that two processes are involved in bringing the basal plate to its final shape and level. The first is the 
formation of the sloping areas cranially and dorsally, which is initiated at the $17 \mathrm{~mm}$. stage and reaches its completion at the $20 \mathrm{~mm}$. stage. The second process is a rotation of the whole basal plate on a transverse axis, resulting in the elevation of its cranial end. This occurs between the 20 and $28 \mathrm{~mm}$. stages. The embryo reconstructed by Macklin (40 mm.) showed little change in this respect from the $28 \mathrm{~mm}$. stage of Levi. According to Levi, the basal plate is formed from two anlagen, occipital and sphenoidal. These are triangular plates of cartilage arranged in such a way as to meet with apices at what will be the center of the basal plate. The base of the occipital anlage, that is the side of the triangle opposite the angle meeting the sphenoid, faces caudad and borders on the foramen magnum. The base of the sphenoidal anlage faces craniad and fuses with the sphenoid body at the crista transversa. The apices of these two triangular cartilages are joined at first only by connective tissue. In the $14 \mathrm{~mm}$. stage, the cartilaginous fusion has just begun. In the $17 \mathrm{~mm}$. stage, it is well established though slender. In the $20 \mathrm{~mm}$. stage it is complete, and the original separation can be made out in the model only by the thinness of the cartilage. In the sections it is easily traced by the manner in which the occipital and sphenoidal regions of the basal plate form their junction, this beginning as a slender process ectally and becoming thicker as the sections are followed toward the cranial cavity, (figs. 4 and 5).

The completion of the basal plate and its fusion to the sphenoid body takes place before there is any cartilaginous otic capsule. The junction of the otic capsule to the basal plate begins in the $17 \mathrm{~mm}$. stage (Levi), when the latter is already complete. This fusion is initiated cranially in the sphenoidal region, and progresses caudally. In the $40 \mathrm{~mm}$. stage, Macklin could still trace a line of separation caudally by the arrangement of the cartilage cells. In the $20 \mathrm{~mm}$. stage, as shown by the sections, the line of union can be traced even cranially (fig. 5,2 ). No separation of basal plate from sphenoidal anlage was found by Levi as early as the $13 \mathrm{~mm}$. stage. This early fusion of the sphenoidal portion of the basal plate to sphenoid body led him 
to describe the cranial portion of the basal plate as part of the orbito-temporal region. The human material at his disposal certainly permitted this interpretation. Gaupp, however, working on the lower vertebrates, has shown that the cranial portion of the basal plate is better ascribed to the otic region. All recent authors have adopted this view. (Voit '09, Mead '09, Macklin '14, DeBurlet '15).

The occipital region, (figs. 1 and 3) then consists of the occipital part of the basal plate mesially, and the paired occipital wings laterally. Cranially it joins the otic portion of the basal plate on a line with the cranial margins of the jugular foramina. The cranial surfaces of the two parts are continuous and form the clivus of the fully developed bone. Laterally the occipital wings border on the otic capsules. A line drawn parallel to the long axis of the basal plate, through the inner edges of the hypoglossal foramina, divides the mesial from the lateral parts of the occipital region.

The mesial part corresponds to the basioccipital of the human adult. It shows two distinct areas, divided by a transverse line through the cranial edges of the hypoglossa canals. The caudal area slopes sharply to foramen magnum. At this point there is a deep notch, the fore-runner of the intercondyloid notch which separates the two prominent condyles. From the notch there passes cranially on the cerebral surface a deep groove, the caudal portion of the clivus, which in the adult supports the pons Varolii. The most caudal part of this groove is in fairly close relation with the odontoid process. From the apex and cranial surface of the dens, a mass of blastema passes craniad which encloses the notochord and completely fills the groove (fig. 5, 3). The notochord passes into the cartilage on the level of the cranial edges of the hypoglossal canals and emerges ventrally and cranially just caudal to the thin area of the basal plate. Thus a large part of the basioccipital is hypochordal.

The mass of blastema filling the clivus is the anlage of the suspensory ligament of the axis.

The ectal surface of the basioccipital (fig. 3) shows an axial ridge which can be traced to the sphenoidal region. This ridge 
at one point shows a prominence, the anlage of the pharyngeal tubercle of the adult (fig. 3, 28).

The cranial area of the basioccipital is horizontal, thus making the angle with the more caudal part, which has been already mentioned in the description of the basal plate. It shows a slight concavity from side to side on the dorsal surface, and a corresponding convexity of the ventral. It gives origin on either side to the cranial root of the occipital wing (fig. 1).

The lateral parts of the occipital region may be said to take origin by two roots with the hypoglossal canal between them. The cranial entrance of this canal is divided on the left side by a thin bar of cartilage (fig. 1, 35). This occupies only about onethird of the length of the canal, which thus appears double regarded from the ental end, but single from the ectal aspect. The two roots join lateral to the canal where they form a narrow flat plate of cartilage with surfaces facing laterad and mesiad. This plate widens quickly into the occipital wing and joins dorsally a thin plate of cartilage which surmounts the otic capsule known as the parietal plate (figs. 1 and 2).

After its junction with the occipital wing, the parietal plate narrows to a thin ribbon of cartilage which turns mesially to meet the corresponding process from the opposite side to form the tectum posterius (fig. 1, 1). The central and lateral parts of the occipital region, in conjunction with the tectum, thus enclose the primitive foramen magnum.

The occipital wing at its origin has two borders, cranial and caudal (fig. 2). The cranial border bounds at first the jugular foramen. It is a sharp ridge and shows at one point a protuberance which Macklin takes to be the jugular tubercle of the adult. Caudal to the jugular foramen the cranial border forms the inner boundary of a space lying between the otic capsule and a lateral extension of the occipital wing known as the lamina alaris. The space is the jugular recess and in the adult condition, contains a portion of the lateral sinus (fig. 7, 3).

The caudal border of the occipital wing bounds the foramen magnum (fig. 3). It passes from the condyle, the ventral foraminal prominence of Macklin, making a concave edge to the 
dorsal foraminal prominence, a protuberance on the edge of the foramen magnum, just below the junction of the occipital wing with the parietal plate. This thick round border has been identified by Bardeen ('10), as the neural arch of the occipital vertebra.

From the lateral aspect of the cranial border of the occipital wing a prominent flange of cartilage protrudes which gives to the occipital wing a lateral extension already mentioned as the lamina alaris (figs. 2, 7, 2). The ventral tip of this structure is known as the paracondyloid process (figs. 2, 6, 1). The lamina as a whole has cranial and caudal surfaces, lateral and mesial borders, dorsal and ventral extremities. Its relation to the occipital wing on the one hand, and to the otic capsule on the other are very important. In the sections it is seen to consist of two parts, as concerns its cartilage, a lateral and a mesial (fig. 5). The mesial part is a lateral protrusion of the occipital wing (fig. 5, 5). The lateral part is a bar of cartilage parallel to the mesial ridge, and in elose contact with it, but showing a separation of its cartilage at certain levels. It is entirely independent at the tip (fig. 6,1). Then for a distance dorsal to the tip it is in close contact with the mesial part, but separated from it by a layer of perichondrium, (figs. 4 and 6, right side). Dorsal to this area of close contact, there is for a distance a fairly wide separation, then an area of complete fusion. Still more dorsally there is again an area of separation (fig. 5), then complete fusion (fig. $7,5)$, which is not again interrupted.

The cranial surface of the lamina alaris forms the caudal boundary of the jugular foramen ventrally, and of the jugular recess dorsally (fig. 1, 4, 34). The caudal surface is free. The mesial edge is in relation to the outer aspect of the occipital wing as already described. The lateral edge is prominent ventrally, becomes low more dorsally, and gradually fades into the outer surface of the occipital wing. It is the inferior nuchal line of the exoccipital portion of the adult bone (fig. 2, 38).

The cranial aspect of the lateral edge of the lamina alaris (fig. $7,5)$, is united to the otic capsule. The point where the two structures first come in contact marks the lateral limit of the 
jugular foramen. Their cartilage is continuous for a short distance dorsal to this point, the line of union being known as the commissura occipito-capsularis (fig. 2, 33). This line of union extends to the apex of the otic capsule, where there is a break in the cartilage known as the fissura capsulo-parietalis. The interruption found by Macklin in his $40 \mathrm{~mm}$. embryo and designated by him fissura capsulo-occipitalis is also present in this embyro.

From the tip of the paracondyloid process there extends mesaid and craniad (figs. 2, 3, 4, 5), a thin process of cartilage which reaches the basioccipital, passing laterad and craniad to the hypoglossal canal. This was found by Macklin in his 40 $\mathrm{mm}$. embryo, where it bounded laterally and cranially a foramen which he termed paracondyloid foramen. It corresponds in position to a ridge of bone which in the adult passes from the tip of the jugular process, mesiad and craniad to basioccipital. It represents, as Macklin suggests, a costal process, not that of the occipital vertebra, but of one of the unsegmented vertebrae since its connections to the basioccipital and occipital wing are craniad and laterad to the hypoglossal foramen.

The paracondyloid process was described by Levi in all the embryos examined by him and figured prominently in his models. He interpreted it to be the tip of the neural arch of the occipital vertebra. Macklin has sufficiently demonstrated the erroneousness of this view, and considers it to represent the transverse process and possibly the costal process of that vertebra.

As has been pointed out the paracondyloid process is but the free extremity of the lamina alaris, and this has been shown to be a bar of cartilage uniting at intervals with a parallel ridge of the occipital. It is therefore suggested that in the lamina alaris are represented the costal and transverse processes of several vertebrae. The outer bar represents the fused costal elements and may be termed the costal bar. The points of union correspond to the bases of the transverse processes, the areas of separation indicate the intervals between the processes of successive vertebrae. If this interpretation prove correct, three such processes can be enumerated. 
That of the occipital vertebra is small and shows no independence of the costal element. It will be noted that this transverse process, although in close contact with the costal bar, has not yet formed a cartilaginous union with it (fig. 4,6). This would indicate that the costal and transverse processes of the occipital vertebra take only a minor part in the formation of the lamina alaris and paracondyloid processes. The second vertebra shows an independent costal element which is drawn out caudad to form the paracondyloid process. From its tip there passes to the basioccipital that bar of cartilage already described as a rib process. It is because of the connection of the paracondyloid process to the basioccipital and occipital wing craniad and laterad to the hypoglassal canal that it is interpreted as the rib process of the second occipital vertebra. The most cranial vertebra helping to form the basioccipital shows no free costal element. The costal bar is prolonged upward on the occipital wing as a ridge which represents, as already said, the inferior nuchal line of the adult bone.

That the occipital region of mammals is made up of a number of vertebrae, all authors agree. The exact number has not been definitely decided. Froriep ('86) found four in calf embryos. Mead states the number as being three.

As far as this present embryo offers any evidence on this point at all, the number would appear to be three, that number of transverse processes and ribs being indicated.

Levi analyzed the human occipital region as follows: The condyles he considered to represent the ununited body of the occipital vertebra; the area between, reaching craniad to the primitive break in the basal plate, he considered as the result of the fusion of the body elements of the unsegmented vertebrae. The paracondyloid process he called the tip of the arch of the occipital vertebra; and the cartilage craniad to the hypoglossal foramen, the fused neural arches of the unsegmented vertebrae. He did not account for the cartilage bordering the foramen magnum dorsal to the condyles.

Macklin considered that the body element of the occipital vertebra also helped form the area between the condyles border- 
ing on the foramen magnum. He represented everything mesiad to a line drawn from the cranial tip of the jugular foramen to the ventral foraminal prominence as containing body elements. The outer part of the condyle he took to be the inferior articular process, the jugular tubercle the superior articular process; the paracondyloid process, the transverse and costal elements; and the thick area bordering the foramen magnum, the neural arch, all belonging to the occipital vertebrae. The neural arch elements of the unsegmented vertebrae he said fused with that of the occipital vertebra, to form the occipital wing, and their pedicles all fused into the comparatively small bar of cartilage cranial to the hypoglossal canal.

There are some objections to this analysis. The jugular tubercle belongs to the structures craniad of the hypoglossal canal. Hence it cannot very well be the superior articular process of the occipital vertebra (fig. 1).

The condyle (fig. 2) cannot be an inferior articular process as found in the cervical vertebrae, since its relations to surrounding structures are fundamentally different. Thus, the condyle is ventral to the transverse process of the occipital vertebra, ventral to the transverse plane through the notochord, and ventral to the suboccipital nerve, whereas the articular processes of the cervical vertebrae are dorsal to these structures (fig. 2).

The condyle has the same relations to the transverse and costal processes of the occipital vertebra and to the chorda as has the lateral mass of the atlas to its transverse and costal processes. As shown by H. Gadow ('96), the atlas may be analyzed as follows: the lateral mass is formed by the fusion of basiventral and basidorsal elements where they meet at the side of the chorda. The basiventral elements, here retained, form the ventral arch of the atlas. The basidorsal elements, form the neural arch of the atlas. The centrum fuses with that of the axis to form the dens epistrophei.

It is possible that the occipital vertebrae are vertebrae of the atlas type. Then the condyles and the tissue immediately dorsal would be formed by fusion at the junction of basiventral and basidorsal elements; the hypochordal elements bordering the 
intercondyloid notch mentioned in describing the course of the notochord, would be basiventrals, and the occipital arch and wing would be fused basidorsals. The centra would be found in the mass of connective tissue which surrounds the chorda and which eventually forms the suspensory ligament of the odontoid process (figs. 4 and 5). The portion of basioccipital dorsal to the chorda remains to be accounted for. Examination of the occipital region of early cat embryos shows that the condylar portions and the hypochordal cartilage joining them ventral to the chorda are formed before there is any suprachordal cartilage. The chorda lies in a dorsal groove and extends craniad without dorsal cartilaginous covering. In later stages cartilage forms about the chorda and covers the cranial portion of the groove in the basioccipital. It is this perichordal element which forms the suprachordal cartilage of the basioccipital and its cranial extension, the clivus. It does not belong to the occipital vertebrae, and its fusion to the occipital region is only owing to the intimate relations of the chorda to both elements.

There is some evidence to support this view of the occipital vertebrae. First, the fact that in some lower animals (Talpa, E. Fischer '01), in early stages the atlanto-occipital joint is horseshoe-shaped, partially surrounding the foramen magnum anteriorly. This articulation may better be interpreted as a joint between the two anterior arches, such as occurs in birds between anterior arches of atlas and axis, (it persists partly in this latter vertebra), than as an articulation between vertebral body and anterior arch, which it would be were the anterior edge of the foramen to consist of body element.

Second, as I have already pointed out, the relation of transverse and costal elements are the same in respect to the lateral mass of the atlas and to the condyle of the occipital cartilage (fig. 2).

Third, the manner of chondrification is much the same. As described by Levi, it begins in the occipital cartilage, (figs. 8, $9, B)$, laterally, just mesial to the hypoglossal canal. These centers unite ventrally, and the chondrification proceeds dorsally, gradually obliterating the groove between the lateral foci. This 
manner of chondrification explains the appearance of the model at this stage, the thick condyles laterally, united ventrally in a ridge but separated dorsally by a deep groove (fig. 6).

The atlas similarly begins to chondrify in its lateral masses, which later unite ventrally to form the anterior arch (figs. 8 and $9, B)$.

In calf embryos Froriep found absorption of the hypochordal arches, the basiventrals, and interpreted the median region of the occipital as derived from the centra of occipital vertebrae. DeBurlet, in Balaenoptera rostrata, has shown the caudal end of the occipital region to be suprachordal in position, not hypochordal, a condition which plainly excludes the possibility of homologizing this region with basiventrals. On the other hand Weiss ('01), working with rat embryos, Noordenbos ('05), with Talpa, and Gaupp with rabbit and opossum embryos, have all shown that in these animals the basioccipital is formed by hypochordal elements. It is evident that we are in need of further investigation of this region.

My embryo shows the oldest cartilage just mesial to the hypoglossal canals, and in the arches close to the outer side of the canals. There is no sign of bone formation.

The occipital wing shows on its outer surface, lateral to the edge of the foramen magnum, the thin area of cartilage known as the paraforminal area (Macklin) (figs. 2,3). There is no sign of the lateral occipital protuberance. On the ental surface the groove between occipital wing and parietal plate, the occipitoparietal groove (Macklin) may be traced, but there is no occipito-parietal fissure (fig. 1). The internal capsulo-occipital groove is well marked; the external, only fairly well (figs. 1,2,3).

The otic region is composed of the otic portion of the basal plate, the paired otic capsules, and the paired parietal plates.

The otic portion of the basal plate (figs. 1 and 3) is thick and wide caudally where it joins the occipital region. This juncture is caudal to the site of that primitive break in the cartilage already described. The plate here is horizontal. Cranially the dorsal surface rises rather sharply, becomes convex, and passes without demarcation into the steeply sloping dorso-caudal sur- 
face of the dorsum sellae. The ventral surface of the otic portion of the basal plate (fig. 3), craniad to the primitive break, becomes convex from side to side and continues its horizontal direction. This divergence of the surfaces causes a dorso-ventral thickening of the cartilage which is much more marked further craniad in the orbito-temporal region (fig. 2). The line of demarcation between otic and orbito-temporal regions may be placed at the beginning of the rise of the surface to the dorsum sellae.

The otic capsules are firmly fused to each side of the otic portion of the basal plate, which they deeply indent and so narrow. Of the character of the fusion, I have already spoken (fig. 5 ). The line of fusion is marked dorsally and ventrally by deep grooves known as the basi-capsular grooves (DeBurlet). These grooves together completely encircle the line of union and meet cranially and caudally in notches, the spheno-capsular and occipito-capsular respectively (figs. 1 and 3 ). The first is the primitive carotid canal, the second is the ventral end of the jugular foramen.

The capsules have two other connections to surrounding parts. The first is caudally through the occipito-capsular commissure to the lamina alaris of the lateral occipital region; the second is dorsally through the capsulo-parietal commissure to the parietal plate (figs. 2 and 7 ).

The otic capsule consists of two parts, (fig. 1) the cochlear, which contains the vestibule and cochlea; and the canalicular, which contains the semicircular canals. While the cartilage of these regions is continuous and the capsule appears in a single mass in reconstruction, on microscopic examination the cochlear part is found to be much younger, an evidence of the retardation of its chondrification, which is the usual condition in mammals. The union between the two is marked cranially and caudally by notches which correspond to the superior and inferior otic notches of Macklin (figs. 1 and 3). Mesially, the surfaces of the two parts pass smoothly into one another without demarcation. The line of union seen from below (fig. 3), is a deep groove in which the facial nerve passes forward to enter the skull by turning dorsad through the superior otic notch. The ventral sur- 
face of the pars canalicularis joins the lateral surface of the pars cochlearis at an angle to form this facial groove which lies at the bottom of the ventro-lateral otic recess of Macklin. This contains the anlagen of the otic ossicles.

The cochlear portion is ventral, cranial and mesial to the canalicular portion (figs. 1 and 3). It is oval, the long axis pointing cranially and mesially. Lateral, mesial and dorsocaudal surfaces are distinguished.

The lateral and mesial surfaces are divided by a rounded border which passes from the peri-lymphatic foramen below, around the cranial pole, to the superior otic notch above. The first part of this border deviates outward to form the promontorium (fig. 3 ,29). It divides the peri-lymphatic foramen from the region of the foramen ovale. The lateral surface is smooth and convex. Dorsally, at the junction. with the ventral surface of the canalicular portion, is the facial groove. The outlines of the fenestra vestibuli cannot yet be made out, as the foot plate of the stapes is buried in indifferent tissue (fig. 3). There is trace of the sulcus caroticus found by Macklin in the $40 \mathrm{~mm}$. stage in the sections (fig. 4, 20).

The dorso-caudal surface is taken up by a large opening, the perilymphatic foramen (fig. 3), which includes the future fenestra cochlearis and the ductus perilymphaticus. The division of these two by a processus interperilymphaticus, well marked in the $40 \mathrm{~mm}$. stage of Macklin, has here scarcely begun (fig. 3, 11), The outer edge of the common opening juts laterad to form the promontory.

The mesial surface is divided by its junction with the basal plate into ventral and dorsal sections. The ventral is smooth, convex, and forms the external wall of the ventral basi-capsular fissure (fig. 3, 9). Above the union with the basal plate the surface is smooth, convex, and continuous dorsally with the surface of the canalicular portion. Cranially the opening of the internal acustic foramen appears (fig. 1). This is rather wide open cranially and mesially. This condition is what we would be led to expect from an examination of the models of Levi. In his model of the $17 \mathrm{~mm}$. chondrocranium, the internal acustic 
foramen gaps widely ventrally, mesially and cranially. Evidently, as comparison with my model shows, enclosure of this foramen by cartilage begins caudally and laterally and proceeds craniad and mesiad. This holds true for the whole cochlear portion, as in Levi's $14 \mathrm{~mm}$. model there is no cartilage about the cochlea except caudally and laterally.

The facial nerve (figs. 1 and 2 ) is directed laterad and craniad from the internal acustic foramen to the cavum supracochleare (Voit), passing between the pars cochlearis and pars canalicularis. It then turns sharply caudad, ventral to the bar of cartilage which unites the pars cochlearis with the pars canalicularis. At this angle where its direction changes, it presents the enlargement of the geniculate ganglion and gives off the great superficial petrosal nerve. The portion of the nerve proximal to the ganglion transverses the primitive facial canal, which has as yet no cartilaginous roof. Conditions here, in view of the theoretical importance of the region, must be discussed in some detail. At the site of the future mesial commissura suprafacialis-this Voit holds to be equivalent to the commissura praefacialis of reptiles - the pars canalicularis sends a small projection mesiad on the dorsal aspect of the nerve (fig. 1, 31). This is directed towards the pars cochlearis, but is far from forming a complete bridge. The commissura is well developed at 40 mm. (Macklin, fig. 6), and at $80 \mathrm{~mm}$. it forms a broad unperforated roof to the facial canal (Hertwig, fig. 658). Fischer, however, states that in a special model by Hertwig of the otic region of this same human embryo, the roof of the facial canal is perforated. In this he finds evidence of the existence of two suprafacial commissures in man, which he previously had ascertained to be the case in Talpa, a medial and a lateral, one crossing the facial nerve proximal, the other distal to the geniculate ganglion. Of this second commissure there is no trace in this embryo, nor does Macklin record its presence at $40 \mathrm{~mm}$. Its very late appearance in man would suggest the possibility of its being of secondary nature, and in so far supports Voit's interpretation of the mesial commissure as the fundamentally important one and equivalent to the commissura praefacialis of rep- 
tiles. It would be desirable to have further information regarding the history of the lateral bar in man, both as regards its constancy and the details of its formation, before accepting as final its interpretation as part of the primitive praefacialis commissure.

In this connection, Voit's observations on the rabbit are of importance. Here the lateral commissura praefacialis is connected plainly with the tegmen tympani and joins the pars cochlearis distal to the geniculate ganglion and, in particular, ventral to the great superficial petrosal nerve. This process is represented in my embryo by a triangular flange of cartilage projecting from the pars canalicularis in the angle of the external genu of the facial nerve (fig. 3, 5). From its position it can, in the embryo, be inferred to be equally capable of reaching the pars cochlearis on either the dorsal or the ventral aspect of the great superficial petrosal nerve.

The pars canalicularis is a three-sided pyramid with its base ventral, apex dorsal, on the dorsal aspect of the pars cochlearis. The surfaces are lateral, cranio-mesial, caudo-mesial. Each border of the triangular outer surface marks the course of one of the semicircular canals, to wit: the anterior border that of the anterior vertical canal, the posterior border that of the posterior vertical canal, the inferior border that of the external canal (fig. 2). The apex corresponds to the highest point in the arch of the anterior vertical canal. The external canal makes a well defined prominence on the outer surface. The course of the others is less clearly indicated in the surface relief.

The cranio-mesial surface is framed by the arch of the anterior vertical canal. Beneath this is a well marked fossa subarcuata. This surface is bounded caudally by a ridge formed by the union of anterior and posterior semicircular canals, the crus communis. This ridge is the dividing line between the two mesial surfaces. Upon this ridge is the opening of the ductus endolymphaticus (fig. 1, 10).

The inferior edge of the external surface is extended downward to bound the outer side of the facial groove. It presents posteriorly a small mastoid process. Cranial to the mastoid process is a prominent ridge, the crista parotica. At the cranial end of 
this inferior border of the external surface, a slender process of cartilage juts forward which Macklin interprets as the anlage of the tegmen tympani (fig. 2, 5).

The base of the pyramid is ventral (fig. 3). It is roughly triangular in shape, with the apex of the triangle covered by the pars cochlearis. The external border is marked by the series of processes already described, to wit: the mastoid process, the crista parotica, the tegmen tympani. To the middle of this border is attached the short process of the incus. At the dorsal extremity of the crista parotica, Reichert's cartilage is received in a depression of the cartilage (fig. 5, 18).

The parietal plate (fig. 2,1 ) is a thin sheet of cartilage which surmounts the pars canalicularis and is continuous with it. Ventrally this ends in a pointed process overhanging the capsule. Dorsally it continues as a thin ribbon of cartilage, turns inwards and meets the process from the opposite side. Thus is enclosed the primitive foramen magnum.

The ventral borders of these parietal plates are continuous with the occipital wings, though the line of union is marked by a groove on the inner surface, the occipito-parietal groove (fig. $1,2)$. Thus they seem in this embryo to have a more intimate union with the otic capsules than with the occipital wings, and they may be considered as forming a true tectum synoticum. In the $40 \mathrm{~mm}$. stage Macklin found a more ventrally placed union of the occipital squama, (the tectum posterius). Above this union he found the parietal plates to end with free dorsal edges. Levi showed that the dorsal union between the two sides occurred cranially and advanced caudally and ventrally, the more cranial union between the parietal plates being absorbed as the ventral union is formed. The conditions in Macklin's $40 \mathrm{~mm}$. and this $20 \mathrm{~mm}$. embryo would appear to bear out this statement of Levi.

The significance of the mode of union of the two sides would seem to be that the tectum synoticum is a more primitive structure and is so formed early, and is absorbed as the tectum posterium reaches its development.

Jacoby was the first to point out that the parietal plates are temporary structures which are early absorbed. Indeed, in the 
$14 \mathrm{~mm}$. embryo of Levi they appear larger proportionately than in this $20 \mathrm{~mm}$. model, and they show successive decrease through his series. We may also conclude that the dorsal extensions of the parietal plates which result in the formation of the tectum synoticum share in the temporary nature of the rest of the structure.

In my description of the otic capsule, I have placed the model with the vertebral column vertical and the basal plate horizontal. After the rotation of the basal plate takes place, the capsule being carried with it, the ventral pole becomes cranial, the cranial pole dorsal. This occurs between the $20 \mathrm{~mm}$. and $28 \mathrm{~mm}$. stages. The change accounts for my using different terms of position from those of Macklin for the same points.

The orbito-temporal region consists of the sphenoid body mesially, and two processes on each side, the alae temporales and the alae orbitales (fig. 1).

I have already described the manner in which the planum basale thickens as it approaches this region. From the crista transversa the prominent dorsum sellae projects cranially and dorsally (fig. 2, 7). This appears to be firmly united to the crista transversa by continuous chondrification, not separated as described by Fawcett ('10), in the 19 and $21 \mathrm{~mm}$. stages. Cranial to this ridge the surface is hollowed by a transverse gutter, the sella turcica (figs. 1 and 2,8). The floor of the sella turcica is formed by the expanded cranial end of the basal plate. Cranial to the sella, the surface rises dorso-craniad to form a limiting wall of the sella in this direction (fig. 1). This wall should be noted, as Levi showed that in the $17 \mathrm{~mm}$. stage, the sella had no wall cranially, making one surface with the lamina hypochiasmatica. The lamina hypochiasmatica (figs. 1 and 2) is a broad flat surface in front of the sella turcica, on a different level. This change of level Levi found established in his $28 \mathrm{~mm}$. embryo, the next oldest in his series. It is however perfectly developed in this embryo of $20 \mathrm{~mm}$. Fawcett does not describe it. Levi makes the point that the floor of the sella retains its original position when the planum basale heaves up and the lamina hypochiasmatica is elevated. It is interesting to note 
that the latter change is pretty well completed when the former has only just begun. The caudo-dorsal edge of the lamina hypochiasmatica is the forerunner of the tuberculum sellae. There are no traces of the middle clinoid processes. The plane of the floor of the sella turcica forms an angle of $115^{\circ}$ with the upper surface of the planum basale. It is from the angle formed by their junction that the dorsum sellae rises.

The lamina hypochiasmatica is limited cranially by a triangular projection dorsad of the caudal extremity of the mesethmoid. This will be described in connection with the ethmoid region (figs. 1 and 8, 6).

At the lateral edge of the lamina hypochiasmatica there are paired little cylinders of cartilage which have their long axes parallel to the plane of its surface (figs. 1 and 3). These are known as the alae hypochiasmaticae (Voit). They are very well developed in the rabbit. Macklin found them well developed in the $40 \mathrm{~mm}$. stage of the human and mentions them as having never been described in man. Fawcett ('10), however, had figured them in the illustrations of his article on the development of the human sphenoid bone, but described them as being continuous with the alae orbitales. The sections show in this embryo (figs. $4,5,6$ ) that they are independent of both ala orbitalis and lamina hypochiasmatica, though they unite later with the dorsal roots of the former (Fawcett) and the sides of the latter (Macklin).

The alae orbitales (figs. 1 and 3) have as yet no connection to the sphenoid. They are S-shaped plates of cartilage which extend craniad and dorsad from the caudal end of the alae hypochiasmaticae. Neither root is as yet formed, though there are indications of the caudal root mesial to the caudal ends of the alae hypochiasmaticae. There are as yet no indications of the ventral, lateral and dorsal extensions found by Jacoby at $30 \mathrm{~mm}$. and Levi at $28 \mathrm{~mm}$., which later unite the alae to the inter-orbital septum, to the ectethmoid, completing the optic foramen and forming the roof of the orbit. Also the dorso-lateral extension, mentioned by Jacoby and Macklin as extending toward the parietal plate and representing the commissura orbitoparietalis of other mammals, is not present. 
The alae temporales (figs. 1 and 3 ) are caudo-ventral to the alae orbitales. In them two parts are distinguished, mesial and lateral (Fuchs '10) (figs. 4, 5, 6). The mesial part, cranially is known as the processus alaris. It is a short bar of cartilage which arises from the ventro-cranial edge of the sphenoid body and extends caudo-laterad. From the point of origin of the lateral part of the temporal wing it continues caudally as the processus ali-cochlearis to the cochlea, with which it comes in contact, but does not unite. This whole process was described by Jacoby as a cartilaginous bridge from the sphenoid to cochlea, from the outer edge of which arose the outer part of the ala temporalis or lamina ascendens. Levi found no trace of it in his models. Macklin described it as approaching the cochlea, but not very closely.

In the region where it might be expected to join the cochlea, he found a separate nodule of cartilage which he called the supracochlear cartilage. The dorsal division, the commissura alicochlearis, is not seen in Hertwig's models. It would appear to be only a temporary structure in man, though found in many mammals (DeBurlet, Olmstead '11, Voit, Fischer). When present, it bounds the carotid canal laterally.

The lateral part of the ala temporalis (figs. 1, 4 and 6), or the lamina ascendens, is a rhomboidal block of cartilage attached by its mesial, dorsal corner to the processus alaris. Its ventral edge is narrow; the dorsal edge is broadened into a flat surface which the foramen rotundum perforates downward and forward (fig. 6). The long axis of the structure points laterad. From its caudal edge arise two processes of dense connective tissue which embrace the third division of the fifth nerve, which is just caudal to the ala temporalis. Thus is indicated the beginning of the foramen ovale (fig. 4).

There is no indication in the orbito-temporal region of any remains of the primitive side wall mesial to the Gasserian ganglion and the structures contained in the cavum epiptericum and cavum supra-cochleare (Voit), such as Voit found in the rabbit. In his $40 \mathrm{~mm}$. reconstruction, Macklin thought this primitive wall might be indicated by the isolated nodule of cartilage at the 
cranial pole of the cochlea, which he called the supra-cochlear cartilage. DeBurlet, in his examination of the primordial cranium of the whale, demonstrated that the commissura alicochlearis, to which that nodule probably belonged, was outside the primitive skull. Examination of the sections show the beginning of the formation of the side wall lateral to the Gasserian ganglion in the form of a dense blastema which passes from the outer side of the pars canalicularis craniad a variable distance to the outer side of the skull vault. In such of the lower mammals as I have examined (cat, opossum, Tupaia) this process is cartilage, and in them forms the parietal plate dorsally and the commissura orbito-temporalis ventrally, which is homologous to the taenia marginata of reptiles (figs. 5 and 7 ).

As concerns its cartilage, the ethmoid region is very rudimentary. The mesethmoid consists of a mesially placed plate of cartilage which begins dorsally as a triangular bar with its base against the cranial surface of the sphenoid body, and its apex projecting upward in front of the lamina hypochiasmatica (figs. 1,2 and 7). In this region, as Macklin points out, it forms the inter-orbital septum, homologous to the inter-orbital septum of reptiles. As it extends forward, the base of the triangle narrows, and distally it forms a flat nasal septum. This gradual flattening can be followed in the sections. At the cranial extremity, the dorsal edge protrudes upward to form the anlage of the crista galli (fig. 2). From the ventral edge of the septum project two slender ridges of pre-cartilaginous tissue which are the anlages of Jacobson's cartilages (fig. 9, $A$ ). They are not connected with the cartilage of the septum, but appear to be in a sheet of dense blastema which extends dorsally on each side of the septum (fig. 3).

The ethmoid region presents laterally two small flat plates of eartilage with their dorsal edges inclining toward the septum (fig. 9, $A$ ). There is only slight indication as yet of cartilaginous turbinates.

Rudimentary as is the cartilage, the nasal cavities as laid down in pre-cartilage are much more complete (fig. $9, A$ ) as shown by examination of the sections, in which septum and side walls can 
be followed from nasal tip to sphenoid body. The connective tissue mentioned by Fawcett as covering in the nasal region at the site of the future nasal bones and the frontal is present.

Lateral and ventral to the nasal region, the maxillae are beginning to form. As Fawcett states, there is one center of ossification. Frontal, palatal, and alveolar processes can be identified (fig. 9, $A$ ).

In the course of the description of my own reconstruction, I have dealt with the differences as compared to the reconstructions of Levi and Macklin.

Von Noorden reconstructed $18.5 \mathrm{~mm}$. and $23 \mathrm{~mm}$. embryos. It is to be regretted that his descriptions and illustrations are not very complete. As compared to the $18.5 \mathrm{~mm}$. embryo described by him, the following advances may be noted in the $20 \mathrm{~mm}$. stage:

1. Formation of foramen rotundum, and outline of foramen ovale. 2. Formation of carotid canal by the extension of the commissura ali-cochlearis to the ventral pole of the cochlea. 3. Appearance of mastoid processes. 4. Joining of the parietal plates to form the tectum posterius. 5. Appearance of maxillae.

Von Noorden states that the optic foramina are formed in his embryo. There is no indication of them in mine.

As compared to Jacoby's $30 \mathrm{~mm}$. embryo, my reconstruction shows (1) much less development of the nasal region. In Jacoby's reconstruction there are well-developed side-walls which are connected with the septum to form the nasal roof. (2) Lack of cartilaginous connection between alae orbitales and pre-sphenoid and ethmoid regions. Examination of Jacoby's model shows that the alae orbitales have three connections to neighboring cartilaginous structures, to wit: to the pre-sphenoid through the taenia post-optica, to the interorbital septum through the prooptica, and to the ect-ethmoid through the cartilago sphenoethmoidalis. All three of these processes are undeveloped in my embryo. This accounts for the absence of the optic foramen and the fissura orbito-nasalis. Another extension of the ala orbitalis, dorsal and caudal toward the parietal plate, present in Jacoby's embryo, is absent in mine. Briefly, at this stage all the 
cranial, lateral and caudal parts of the orbital wings have not begun to develop. (3) Almost the entire absence of the turbinates, which Jacoby finds beginning to form. Levi mentions them as being already cartilaginous in his $28 \mathrm{~mm}$. embryo. (4) There are, in my embryo, no external pterygoid processes, which Jacoby found in his.

In the sphenoid region, my embryo seems, in certain respects, more developed, as it shows a posterior clinoid process, a foramen rotundum, and incomplete foramen ovale.

As compared to the fully developed chondrocranium, my model lacks (1) in the nasal region, the nasal roof, the lamina cribrosa, the connection between ala orbitalis and sphenoid, and the turbinates. (2) In the sphenoid region there is no optic foramen; the alae orbitales are poorly developed and are not connected with the sphenoid body; the pterygoid is lacking. (3) In the otic region, the tegmen tympani has only just begun to form. (4) In the occipital region, the disproportionate size of the foramen magnum at once attracts attention, due to the occipital wings not having met in the midline. The paracondyloid processes are disproportionately large; in later stages they undergo absorption. The fact that they are not yet entirely fused with the occipital squama should be particularly noted.

As to the light which this reconstruction throws on the course of the development of the skull, this may be said: The basal plate first fully develops. The occipital squamae develop and unite about the foramen magnum, first through the slender band of cartilage which connects the partes canaliculares and fuses with the squama by its caudal edge.

The development of the otic capsules and sphenoid body takes place about the same time, and the otic capsules then fuse to basal plate and occipital squamae. The orbital and temporal wings of the sphenoid region next appear, and a little after them the nasal septum and lateral nasal parts. This is about the stage of my embryo.

The next step (Levi) is the elevation of the ventral end of the basal plate, involving rotation also of the otic capsules through almost one-quarter of a circle. This causes the ventral ends of 
basal plate and otic capsules to take a dorsal position. The nasal region, orbital wings, are now developed and ossification sets in, first in the maxillae and mandibles. From the $20 \mathrm{~mm}$. stage to the 40 , the brain cavity expands laterally becoming wide and shallow instead of narrow and deep.

\section{LITERATURE CITED}

(1) BARDEwn, C. R. 1910 Morphogenesis of the skeletal system. Human Embryology by Keibel and Mall.

(2) DeBurlet, H. M. 1915 Zur Entwicklungsgeschichte des Walschädels. III. Das Primordialeraniums eines Embryo von Balaenoptera rostrata. Morph. Jahrbuch, Bd. 49.

(3) FawcetT, E. 1910 Notes on the development of the human sphenoid. Jour. Anat. and Physiol., vol. 44.

(4) Fiscren, E. 1901 a Das Primordialeranium von Talpa europeae. Anat. Hefte, Bd. 17.

1901 b Bemerkungen üher das Hinterhauptgelenk der Sänger. Anat. Anz., Bd. 19.

1901 c Zur Kenntnis des Primordialeraniums der Affen. Anat. Anz., Bd. 20.

(5) Froriep, A. 1886 Zur Entwicklungrsgeschichte der Wirbelsäule, insbesondere des Atlas und Epistropheus und der Occipital Region. Archiv für Anat. und Physiol., Anat. Abth.

(6) Fuchs, H. 1910 Über das Pterygoid, Palatinum und Parasphenoid der Quadrupeden, insbesondere der Reptilien und Säugetiere, nebst einigen Betrachtungen $\ddot{b}$ ber die Beziehungen zwischen nerven-und Skelettcilen. Anat. Anz., Bd. 36.

(7) Gadow, H. 1896 On the evolution of the vertebral column of Amphibia and Amniota. Phil. Trans. of the Royal Soc. of London, vol. 187.

(8) Gaupp, E. 1900 Das Chondrocranium von Lacerta agilis. Ein Beitrag zum Verständnis des Amniotenschä dels. Anat. Hefte, Bd. 15, Abt. 1.

(9) JАCовx, M. 1894 Ein Beitrag zur Kenntniss des menschlichen Primordialcraniums. Archiv für. mikr. Anatomie, Bd. 44.

(10) Kolliker, A. 1849 Allgemeine Betrachtungen über die Enstehung des knöckernen Schädels der Wirbelthiere. Berichte von der königl. zool. Anstalt. zu Würzburg.

(11) Levi, G. 1900 Beitrag zum Studium der Entwickelung des knorpeligen Primordialcranium des Menschen. Archiv. für mikr. Anatomie, Bd. 55.

(12) Macklin, C. C. 1914 The skull of a human foetus of $40 \mathrm{~mm}$. Am. Jour. of Anat., vol. 16.

(13) Mead, C. S. 1909 The chondrocranium of an embryo pig, Sus scrofa. Am. Jour. Anat., vol. 9.

(14) Noondenbos, W. 1905 Úber die Entwickelung des Chondrocraniums der Säugethiere. Petrus Camper, Deel., Bd. 3, Abt. 3, vol. 4. 
(15) Olmstead, M. P. 1911 Das Primordialeranium eines Hunde-embryo. Ein Beitrag zur Morphologie des Säugetierschadels. Anat. Hefte., Abt. 1., Bd. 43.

(16) Werss, A. 1901 Die Entwickelung der Wirbelsäule der weissen Ratte, besonders der vördersten Halswirbel. Zeitschr. f. wiss., Zool. Bd. 69.

(17) Vort, M. 1909 Das Primordialcranium des Kaninchens unter Berüchsichtigung der Deckknochen. Anat. Heft, Br. 38.

(18) von Noonden, W. 1887 Beitrag zur Anatomie der knorpeligen Schädelbasis menschlichen Embryonen. Archiv. für Anatomie und Physiologie, Anat. Abth.

\section{FIGURE 1}

Dorsal view of chondrocranium, $20 \mathrm{~mm}$. human embryo.

1, Tectum posterius

2, Sulcus occipito-parietalis

3, Sinus lateralis

4, Foramen jugulare (Occipito-capsular noteh)

5 , Foramen hypoglossi

6, Dens epistrophei

7 , Chorda dorsalis

8, Planum parietale

9, Fissura parieto-capsularis

10, Foramen endolymphaticum

11, Nervus facialis

12, Ganglion geniculatum

13, Sulcus basicapsularis dorsalis

14. Nervus petrosus superficialis major

15, Foramen ovale

16, Foramen rotundum

17, Foramen caroticum (Spheno-capsular notch
18, Dorsum sellae

19 , Septum interorbitale

20, Maxillo-turbinal

21, Crista galli

22, Septum nasi

23, Paries nasi

24, Lamina hypochiasmatica

25, Ala hypochiasmatica

26, Ala orbitalis

27, Processus alaris

28, Ala temporalis

29, Processus alicochlearis

30, Porus acusticus internus

31, Processus praefacialis

32, Fossa subarcuata

33, Ridge of crus communis

34 , Recessus jugularis

35 , Bar dividing foramen hypoglossi

36. Cranial root of occipital plate 

JOHN D. KERYA.N, JR.

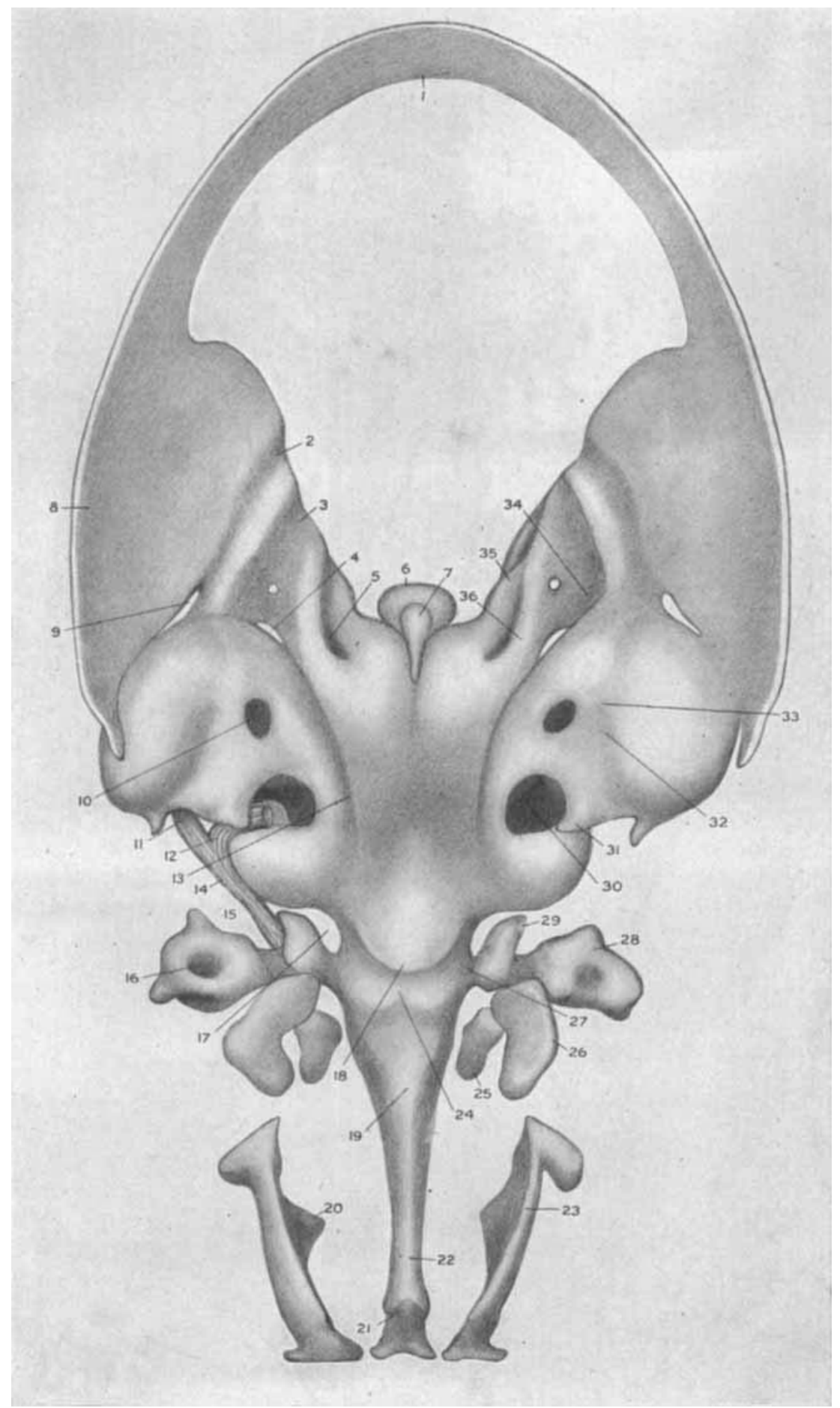


FIGURE 2

Right side of chondrocranium and anterior cervical vertebrae of a $20 \mathrm{~mm}$. human embryo.

1, Planum parietale

2, Fissura parieto-capsularis

3, Canalis semicircularis superior

4, Stapes

5 , Tegmen tympani

6, Pars cochlearis

7 , Dorsum sellae

8 , Sella turcica

9, Ala orbitalis

10, Ala hypochiasmatica

11, Paries nasi

12, Maxilla

13, Anlage of cartilago paraseptalis

14, Septum nasi

15, Ala temporalis

16, Processus alicochlearis

17, Meckel's cartilage

18 , Mandibula

19, Manubrium mallei

20, Ineus
21, Processus longus incudis

22, Chorda tympani

23, $N$. facialis

24, Reichert's cartilage

25, Canalis semicireularis inferior

26 , Costal process 2 nd occipital verte bra

27, Arcus anterior atlantis

28, Processus mastoideus

29, Dens epistrophei

30, Processus costalis atlantis

31, Processus transversus atlantis

32, Processus paracondyloideus

33. Commissura occipito-capsularis

34, Arcus atlantis posterior

35. Costal bar, Lamina alaris

36, Paraforminal area

37, Fissura occipito-capsularis

38 , Crescentic ridge

39, Tectum posterius 


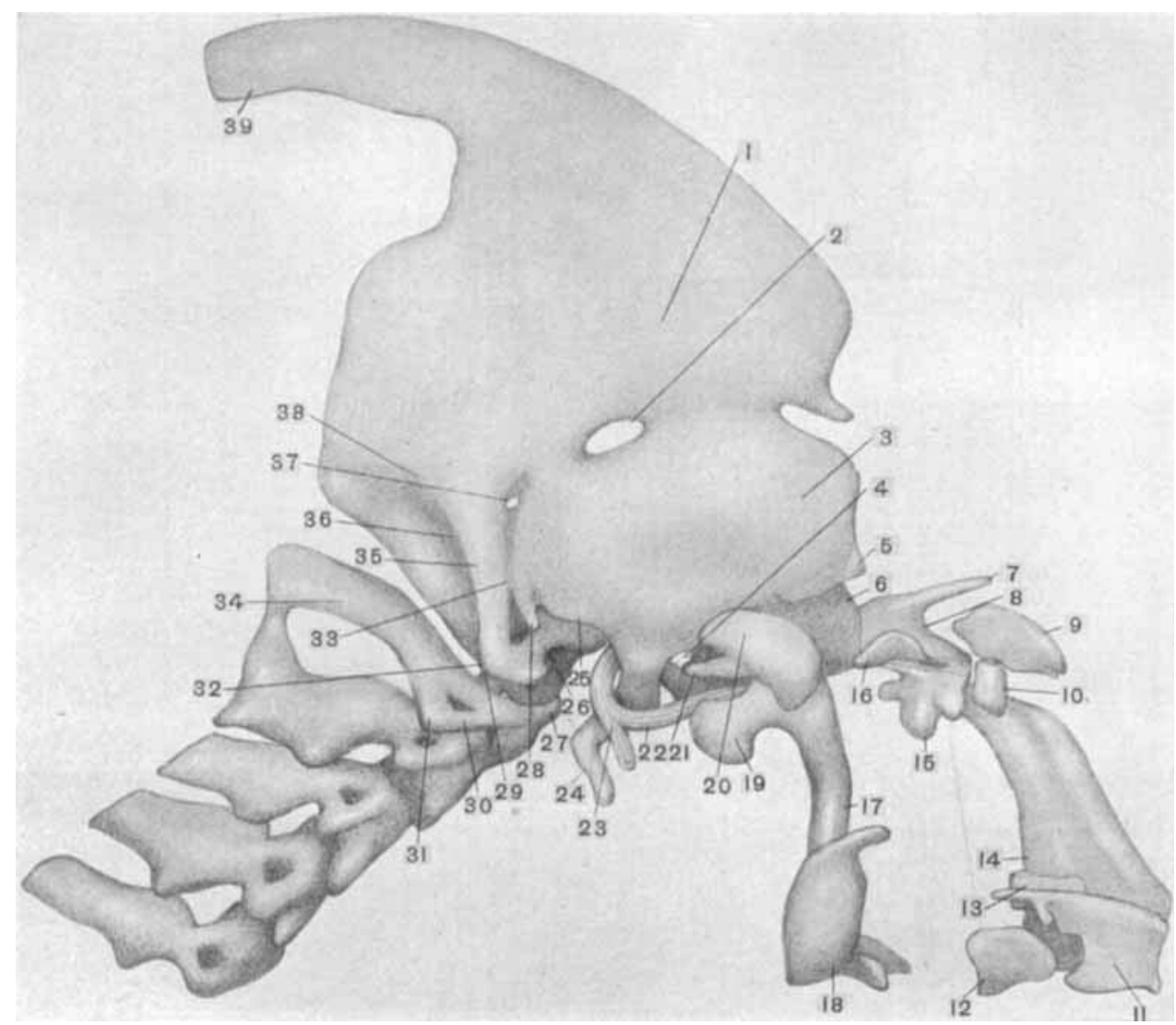


FIGURE 3

Ventral view of chondrocranium of a $20 \mathrm{~mm}$. human embryo.

1, Paries nasi

2, Maxillo turbinal

3 , Anlage of cartilago paraseptalis

4, Ala hypochiasmatica

5 , Ala orbitalis

6, Processus alaris

7, Ala temporalis

8, Processus ali cochlearis

9 , Sulcus basicapsularis ventralis

10, Tegmen tympani

11, Processus interperilymphaticus

12, Sulcus facialis

13 , Stapes

14, Crista parotica

15, Foramen perilymphaticum

16, Processus paracondyloideus

17 , Processus mastoideus

18, Prominentia foraminalis posterior
19, Processus costalis et transversus, occipital vertebra

20, Foramen jugulare

21, Prominentia foraminalis anterior (condylus)

22, Intercondyloid notch

23, Hyale

24, Processus longus incudis

25, Incus

26, Malleus

27, Maxilla

28, Pharyngeal tubercle

29, Thin area in basal plate

30, Promontorium

31, Rib element, 2nd occipital vertebra

32, Chorda dorsalis

33, Hypophyseal stalk 


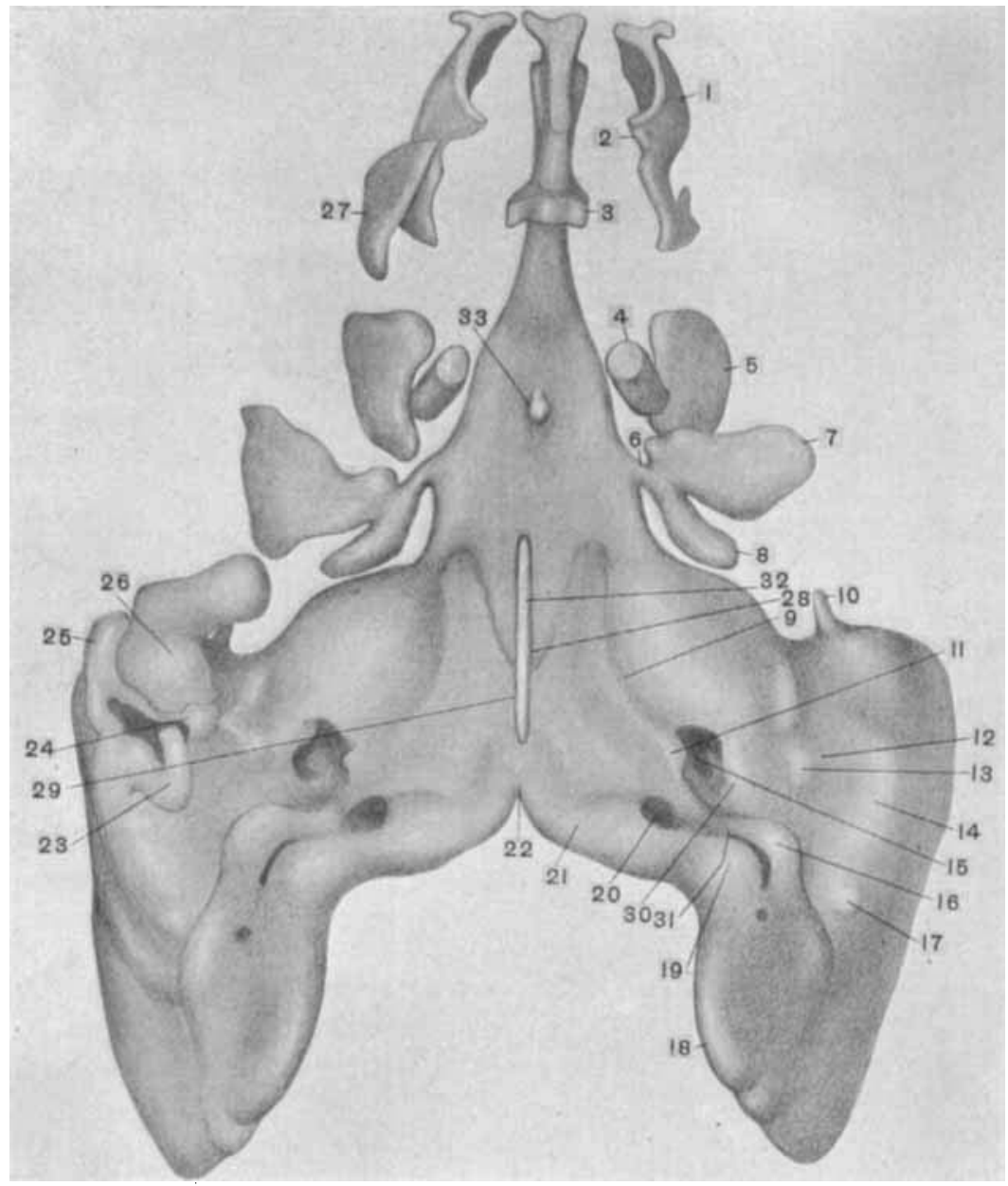




\section{FIGURE 4}

Section of $20 \mathrm{~mm}$. human embryo, nearly parallel to basal plate.

1. Slender area of basal plate

2. Blastemal anlage of ligamentum dentis epistrophei

3, Costal bar of lamina alaris

4. Transverse and costal process, occipital vertebra

5, Cranio-mesial extension of costa bar

6, Perichondrial layer separating costal bar and transverse process of occipital vertebra

7 , Ala hypochiasmatica

8, Ala temporalis, processus alaris
9, Ala temporalis, processus ascendens

10, Foramen rotundum

11 , Foramen ovale

12, Processus alicochlearis

18, Chorda dorsalis

14. Hypophyseal stalk

15, Malleus

16 , Incus

17 , Stapes

18, Reichert's cartilage

19 , Interhyale

20, Arteria carotis

21 , Foramen perilymphaticuin 
JOHN D. KERNAN, JR

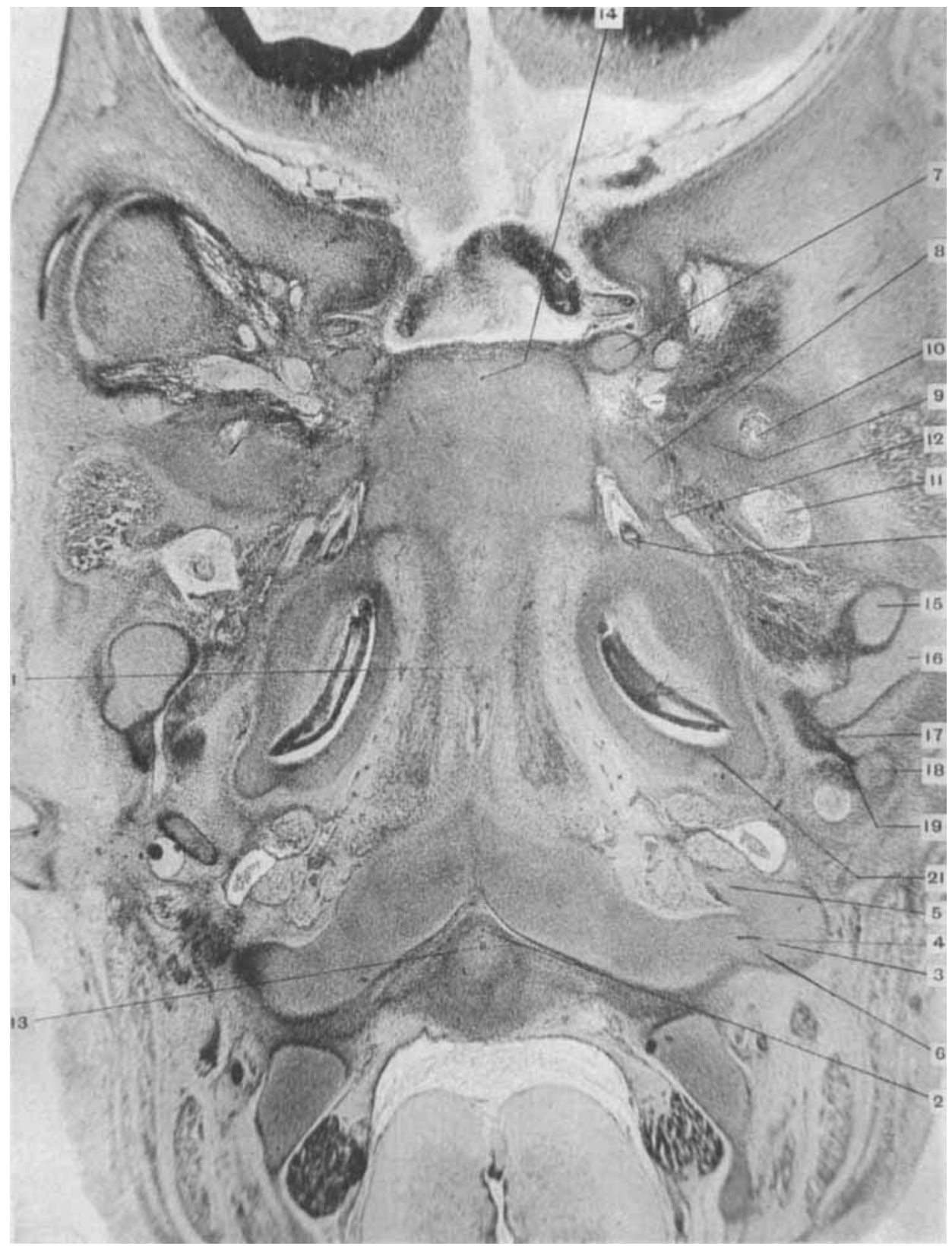


FIGURE 5

Section of head of human embryo of $20 \mathrm{~mm}$., parallel to planum basale, but at higher level than plate 4.

1 , Slender area of basal plate

2, Union of otic capsule to basal plate

3, Anlage of ligamentum dentis epistrophei

4. Costal bar of lamina alaris

5 , Transverse process of oceipital vertebra

6 , Layer of perichondrium separating costal bar from transverse process

7, Cranio-mesial process of paracondyloid process

8, Reichert's cartilage
9, Ala orbitalis

10, Distal extremity, processus ali cochlearis

11. Membranous anlage of side wall of skull

12, Stapes

13, Malleus

14, Incus

15 , Interhyale

16, Crista parotica

17, Proximal end, Reichert's cartilage

18, Processus mastoideus 
JOHN D, KERNAN, JR.

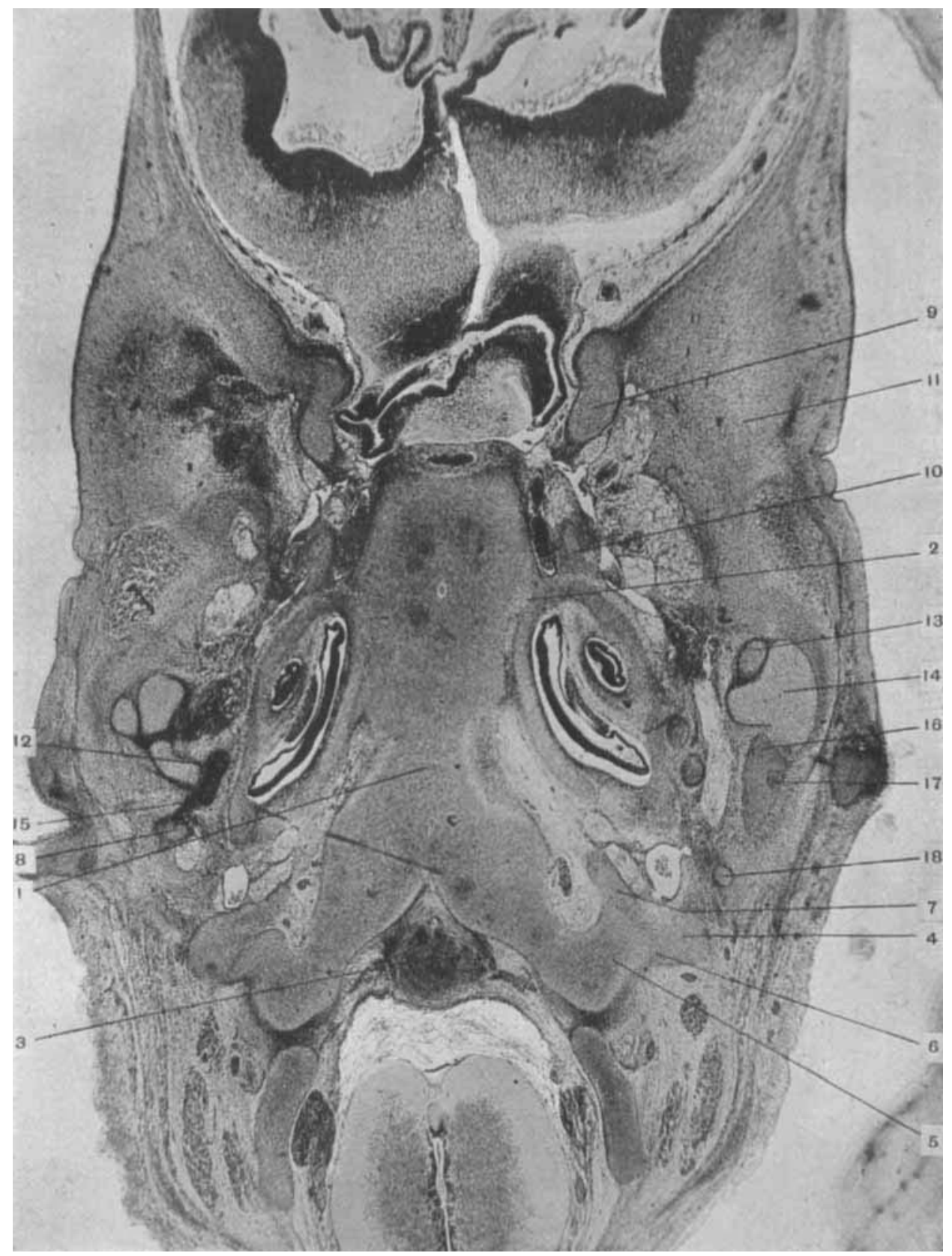


FIGURE 6

Section of head of $20 \mathrm{~mm}$. human embryo, passing through lower part of eye and through occipital vertebra.

1, Tip of paracondyloid process

2, Lateral masses of oceipital vertebra

3, Anterior arch of oceipital vertebra 4, Chorda dorsalis

5 , Dens epistrophei

6 , Neural are $h$ of atlas

7. Ala hypoc hiasmatica
8, Processus alaris of ala temporalis

9. Processus ascendens of ala temporalis

10, Foramen rotundum

11, Nervusopticus

12, Nervusfacialis

13, Chorda tympani

14, Cavum tympani 
JOHN D. KERNAXN, MR.

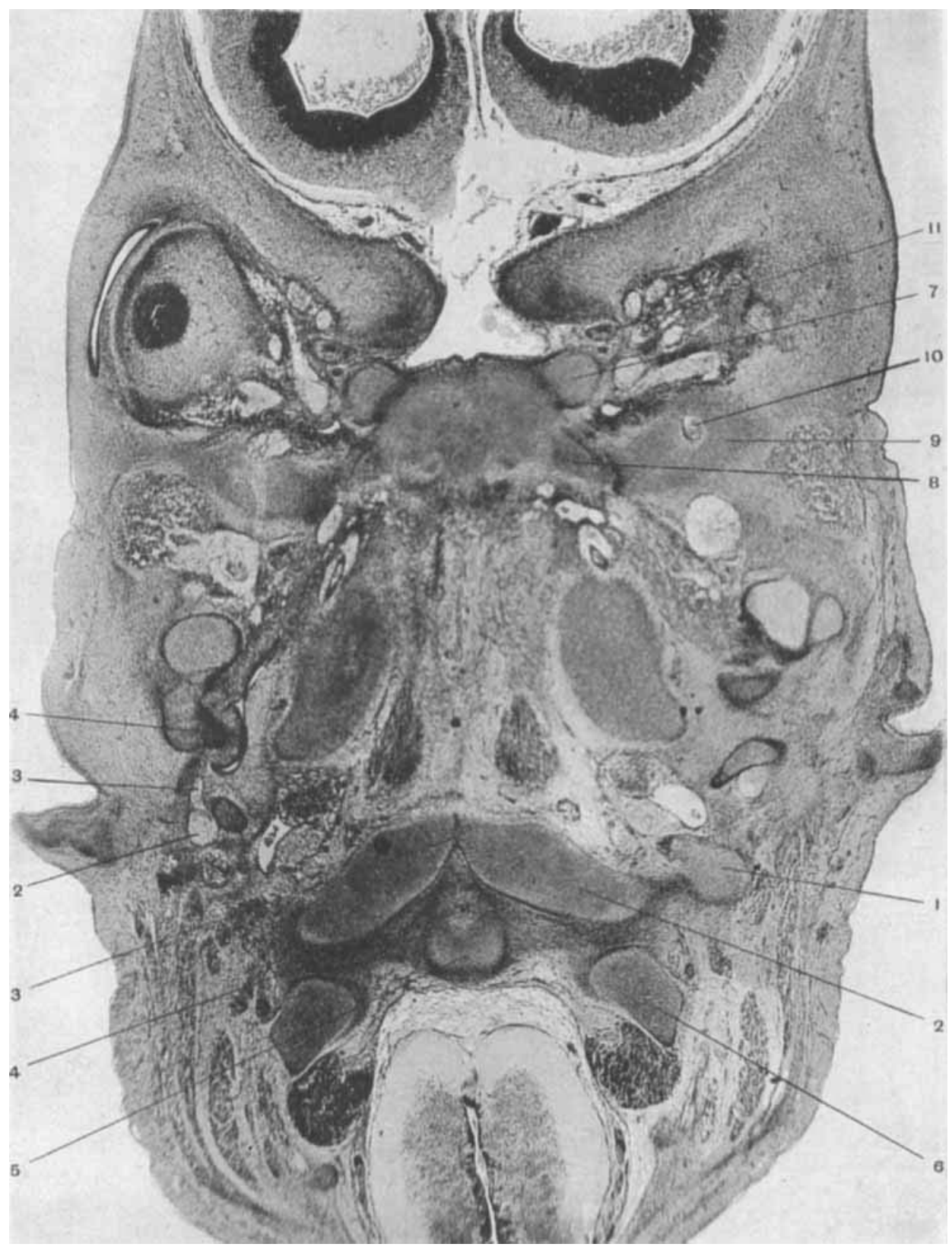




\section{FIGURE 7}

Section of head of $20 \mathrm{~mm}$. human embryo, passing through foramen magnum, otic capsules and tip of dorsum sellac.

1, Occipital wing

2, Lamina alaris

3, Jugular recess

4. Internal occipito-capsular groove

5 , Commissura occipito-capsularis

6 Utriculus
7 , External canal

8 , Posterior canal

9, Membranous anlage of side wall of skuil

10, Tip of dorsum sellae

11, Commissura praefacialis 
JOHN D, KERNAN, JR.

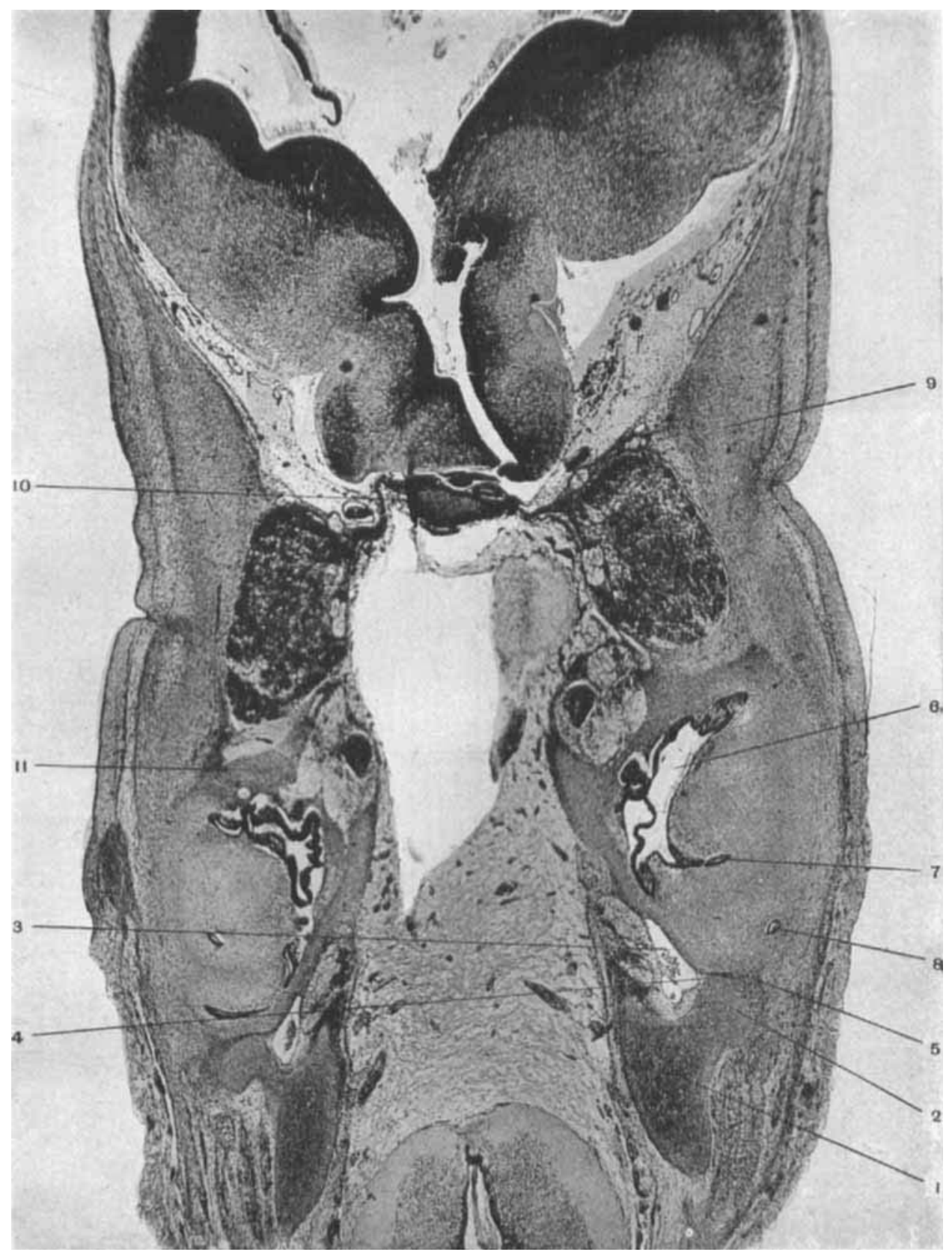




\section{FIGURE 8}

Section of head of $20 \mathrm{~mm}$. human embryo passing through epistropheus, atlas, and interorbital septum.

1 , Lateral mass of atlas

2, Caudal tips of condyles

3, Anterior arch of atlas

4 , Anterior arch of occipital vertebra

5 , Base of densepistrophei
6 , Interorbital septum

7 , Reichert's cartilage

8 , Meckel's cartilage

9, Manubrium mallei

10, Ventral tips of alae temporales 
JOHN D. KERNAN, JR.

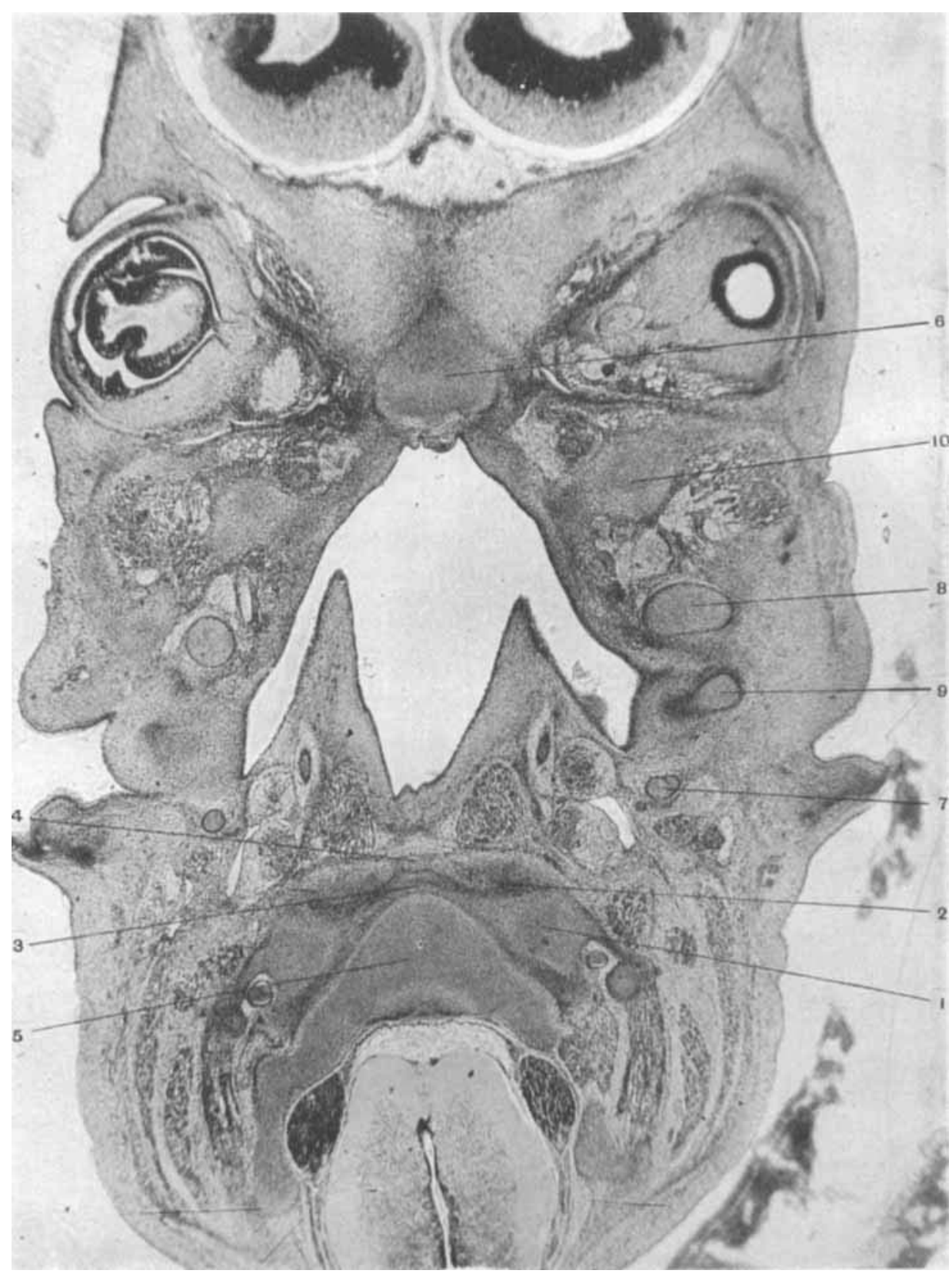




\section{FIGURE 9}

A. Section through nasal region and lower jaw of $20 \mathrm{~mm}$. human embryo.
1. Septum nasi
5 , Mandibula
2, Paries nasi
6, Cavum oris
3, Maxilla
7 , Tongue

4, Reichert's cartilage

$B$. Chondrification of atlas. Section through atlas and epistropheus of a 20 mm. human embryo

1, Lateral masses of atlas

2, Anterior arch of atlas
3, Body of epistropheus

4, Arch of epistropheus 
JOHN D. KERNAN, JR.
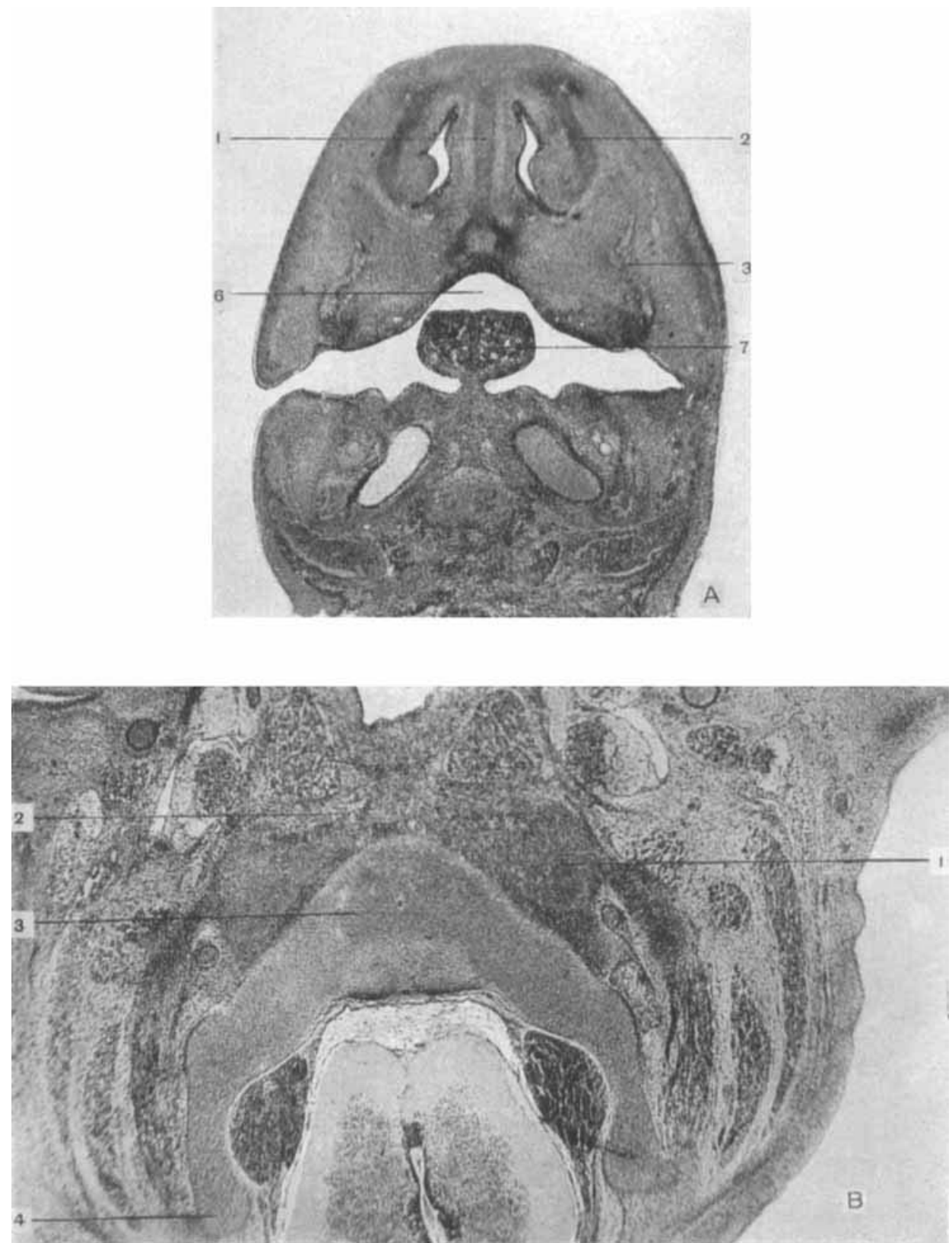